\title{
Wild and Cultivated Cherries - Antioxidant Capacity Analysis
}

\author{
Marian Topolov, (PhD) \\ Medical University, 15A Vasil Aprilov bul., Plovdiv, 4002, Bulgaria; \\ Department of Pharmacology and Drug Toxicology, Faculty of Pharmacy \\ Tihomir Dermendjiev, (PhD) \\ Medical University, 15A Vasil Aprilov bul., Plovdiv, 4002, Bulgaria; \\ Department of Microbiology and Immunology, Faculty of Pharmacy \\ Stanislav Phortunov, \\ Medical University, 15A Vasil Aprilov bul., Plovdiv, 4002, Bulgaria; \\ Student 5th course Pharmacy, Faculty of Pharmacy
}

Doi: 10.19044/esj.2017.v13n33p44 URL:http://dx.doi.org/10.19044/esj.2017.v13n33p44

\begin{abstract}
Cherries are fruit that is rich in powerful antioxidants (anthocyanin) and many different stimulating good health substances.

SCOPE: Determination and analysis of $\mathrm{pH}$, total phenols, antioxidant activity (radical trapping activity) total anthocyanin of wild growing and cultivated varieties of cherries.

Research Methods Applied:

- $\quad$ Systematic approach and critical analysis of the available scientific periodicals;

- $\quad$ Spectrophotometric method for determination of adsorption and standard Gallic acid;

- DPPH method for determining the antioxidant activity (radical trapping activity). The results presented are the mean values of at least three parallel tests. The total phenols of the samples we studied are in the range of 0.57 to $1.67 \mathrm{mg} \mathrm{GAE} / \mathrm{g}$ fresh weight. Total anthocyanin in the samples we tested was in the range of 0.02 to $0.44 \mathrm{mg} / \mathrm{g}$ of fresh weight. Antioxidant activity of 7.88 to $16.20 \mathrm{~mol} \mathrm{TE} / \mathrm{g}$ fresh weight $\mathrm{pH}$ of 3.70 to 4.19. CONCLUSION: Common anthocyanin is highest in early sorts of cultivated cherries. In later ripening varieties of cultivated cherries, the value of common anthocyanin is significantly lower. In addition, this indicator depends on the altitude of the cultivated cherry. The antioxidant activity is highest in the variety Wild Cherry (Banya, Karlovo), Early Cherry Van (Radilovo), Van variety (Isperihovo) and Cartilage Bing variety or Bigato
\end{abstract}


Burla (Novo Selo). Therefore, this indicator depends on the altitude and ripening time of the fruit.

Keywords: Cherries, phenols, anthocyanin, antioxidant activity, $\mathrm{pH}$

\section{Introduction}

Cherries are fruit that is rich in powerful antioxidants (anthocyanin) and many different stimulating good health substances.

They are rich in flavonoids. They contain quercetin - powerful antiinflammatory substance that relieves pain in the joints and protects against eye diseases. Cherries are rich natural source of vitamin $\mathrm{C}$ that helps the production of collagen, maintains the healthy appearance of the skin and hair and successfully fights the viruses and bacteria. Phenols are hydroxyl derivatives of benzene, wherein the hydroxyl group is directly attached to the aromatic nucleus.

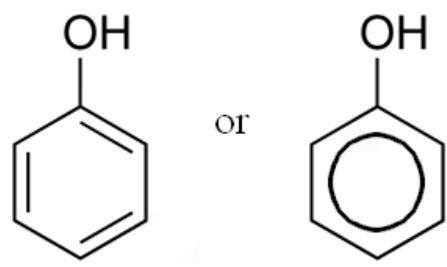

Depending on the number of hydroxyl groups, the phenols are monovalent, divalent, trivalent and polyvalent. More complex phenols can contain more than one phenolic residue in their molecule and are therefore divided into monophenols, diphenols, triphenols and polyphenols. The most famous monovalent monophenol is carbol.

Polyphenols are:

- Tannins

- $\quad$ Lignins

- Flavonoids (Catechins, leucoanthocyanidins, dihydrochalcone, halcones, anthocyanidin, anthocyanin, flavones, flavonols, flavanolol)

According to the National Cherry Growers \& amp; Industries Foundation in USA: The potential role of sweet cherries in cancer prevention is due mainly to the content of anthocyanins, especially cyanidine. 


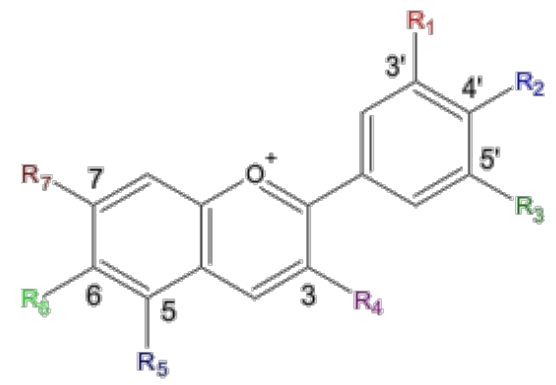

Anthocyanins general formula<smiles>Oc1cc(O)c2cc(O)c(-c3ccc(O)c(O)c3)[o+]c2c1</smiles>

Цианидин

cyanidine

Cherries contain ellagic acid - a powerful chemical compound blocking an enzyme required for the development of cancer cells. Cherries are also rich in anthocyanin - antioxidant used by the body in the production of substances to prevail disease.

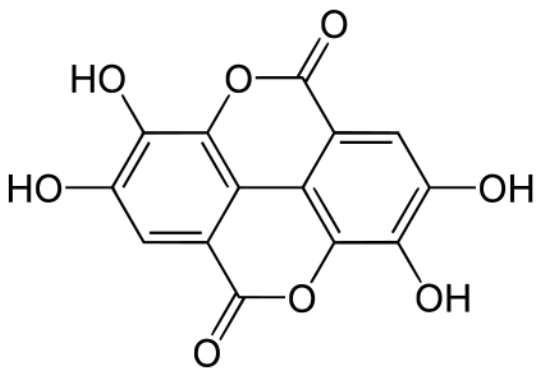

Ellagic acid

The fruit also has anti-inflammatory properties that relieve suffering such as rheumatoid arthritis and gout.

SCOPE: Determination and analysis of $\mathrm{pH}$, total phenols, antioxidant activity (radical trapping activity) total anthocyanin of wild growing and cultivated varieties of cherries. 


\section{Material and methods}

Object of the study: Antioxidant characteristics of wild growing and cultivated cherry varieties.

Wild Cherry (Banya, Karlovo - 295 m. altitude)

Early Van Cherry (Radilovo - 367 m. altitude)

Van Cherry (Isperihovo - 234 m. altitude)

Cartilage Bing or Bigato Burla (Novo Selo - 170 m. altitude)

Timespan: Timespan of the study - May through July $2017 \mathrm{y}$.

Place of study: Laboratory of the University of Food Technologies Plovdiv and Laboratory of Pharmaceutical Analysis of the Medical University of Plovdiv.

Research Methods Applied:

Systematic approach and critical analysis of the available scientific periodicals;

Spectrophotometric method for determination of adsorption and standard Gallic acid;

DPPH method for determining the antioxidant activity (radical trapping activity).

Used Apparatus:

Analytical scale KERN ABJ 220-4M;

Spectrophotometer Camspec M107, UK; pH-determiner;

Standardised $\mathrm{pH}$ determiner with $\mathrm{pH}$ 4,0 and 7.0 standard buffer solutions (WTW inoLab pH 7110, Germany);

Standardised $\mathrm{pH}$ meter with $\mathrm{pH} 4,0$ and 7.0 standard buffer solutions Denver Instrument Ultra Basic.

Reagents and solutions:

To determine common phenols:

$7.5 \% \mathrm{Na} 2 \mathrm{CO} 3$ and Folin-Ciocalteus phenol reagent (Sigma) - a 5 times diluted reagent is used.

To determine antioxidant activity by DPPH method:

0,1 M DPPH reagent: 10 mg.DPPH (2,2-Diphenyl-1-picrylhydrazil) dilutes in $250 \mathrm{ml}$ methanol.

To determine common antocyanins:

Buffer with pH 1.0 (potassium chloride, $0.025 \mathrm{M}$ )

Buffer with pH 4.5 (sodium acetate, $0.4 \mathrm{M}$ )

$\mathrm{HC} 1$ (to adjust $\mathrm{pH}$ )

Sample preparation.

Samples of fresh cherries are cut into pieces and then homogenized with a blender to a homogeneous mass. Weigh 8 grams (analytical scale KERN ABJ 220-4M) from the sample and quantitatively transfer it into a $50 \mathrm{ml}$ volumetric flask with ethanol and volume is brought to the mark. The sample is homogenized and stays at room temperature for 15 minutes. 
Analysis Path to determine COMMON PHENOLS

Place $0.2 \mathrm{ml}$ of sample solution in a cuvette then place $1.0 \mathrm{ml}$ of FolinCiocalteus phenol reagent (diluted 5 times) and $0,8 \mathrm{ml} \mathrm{7,5 \%}$ solution of $\mathrm{Na} 2 \mathrm{CO} 3$. For control sample, the same reagents were prepared, but instead of $0,2 \mathrm{ml}$ sample there were placed $0.2 \mathrm{ml}$ solvent. The samples thus prepared are kept for 20 minutes at room temperature. Adsorption of the sample is measured spectrophotometrically against a control with wavelength $765 \mathrm{~nm}$ (Camspec M107, UK). The amount of common phenols is reported according to a pre-set standard gallon acid right: $\mathrm{Y}=12,557 \mathrm{x}$ 0.0871 .

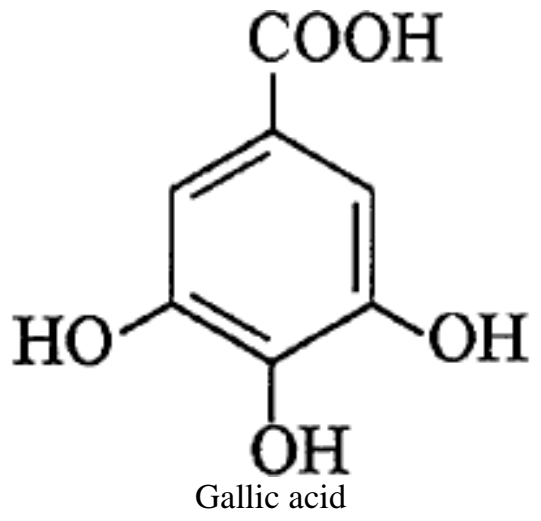

Calculations: $\mathrm{mg} \mathrm{GAE} / \mathrm{g}$ f.s $=(\mathrm{VxC}) / \mathrm{M}$

Where:

GAE - gallic acid equivalent

f.s. - fresh substance, $\mathrm{g}$.

$\mathrm{V}$ - volume of the extract, $\mathrm{ml}$.

$\mathrm{C}$ - concentration of phenols in the eextract read by standard straight, $\mathrm{mg} / \mathrm{ml}$

$\mathrm{M}$ - weight of extracted plant material, $\mathrm{g}$.

Path of the method for determining the antioxidant activity (radical trapping activity) using DPPH method.

Place in a cuvette $2,85 \mathrm{ml}$ of $0,1 \mathrm{M} \mathrm{DPPH}$ after that place $0,15 \mathrm{ml}$ of sample. For the control, the same reagents were prepared but a solvent was placed instead of a sample. Thus prepared samples are kept $15 \mathrm{~min}$ at $37^{\circ} \mathrm{C}$. Adsorption of the sample is measured spectrophotometrically against a control (solvent methanol) at a wavelength of $517 \mathrm{~nm}$ (Camspec M107, UK). Antioxidant activity is reported according to a pre - established standard

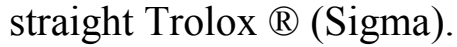

Calculation:

C, m. mol TE $/ \mathrm{ml}=102.06 . \mathrm{I} \%+0.7954$

m. mol TE/ g. fresh weight $=(\mathrm{VxC}) / \mathrm{M}$. 
Where:

C- concentration, -TROLOX equivalents.

I - percentage inhibition.

A- Absorption.

$\mathrm{M}-$ Weight of the sample, $\mathrm{g}$.

V-Volume of the sample, $(100 \mathrm{ml})$.

Path of the analysis to determine COMMON ANTHOCYANINS

(A) buffer with $\mathrm{pH} 1.0$ (potassium chloride, $0.025 \mathrm{M}$ ). - Weigh 1,86 g KCl in a cup and add distilled water around $980 \mathrm{ml}$. Measure $\mathrm{pH}$ and correct $\mathrm{pH}$ to 1.0 ( \pm 0.05 ) with $\mathrm{HC1}$ (approximately $6.3 \mathrm{ml}$ ). Transfer to a 1 liter volumetric flask and dilute to the mark with distilled water;

(B) Buffer with $\mathrm{pH} 4.5$ (sodium acetate, $0.4 \mathrm{M}$ ). - weigh 54.43 g CH3C02 $\mathrm{Na} \times 3 \mathrm{H} 20$ in a cup and add distilled water up to $960 \mathrm{ml}$. Measure $\mathrm{pH}$ and correct $\mathrm{pH}$ to $4.5( \pm 0.05)$ with HCI (approximately $20 \mathrm{ml})$. Transfer to a 1 liter volumetric flask.

Determine the absorbance of the sample diluted with pH 1.0 (6 times) with

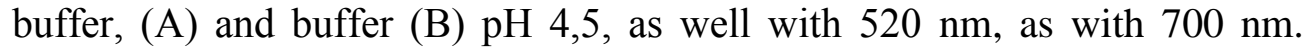
Diluted test samples are scored against a blank sample filled with distilled water.

Calculate the concentration of anthocyanin pigments expressed as cyanidin3-glucosidic equivalents as follows:

Anthocyanin pigments (cyanidin-3-glucosidic equivalents, $\mathrm{mg} / \mathrm{L})=(\mathrm{A} \mathrm{x}$ MW x DF x 103) / e

where $\mathrm{A}=(\mathrm{A} 520 \mathrm{~nm}-\mathrm{A} 700 \mathrm{~nm}) \mathrm{pH} 1.0$ - (A $520 \mathrm{~nm}-\mathrm{A} 700 \mathrm{~nm}) \mathrm{pH}$ 4.5;

MW (molecular weight $)=449,2 \Gamma / \mathrm{mol}$ for cyanidin-3-glucosidic;

$\mathrm{DF}=$ dilution factor.

$\mathrm{e}=26900$ molar extinction coefficient in $Л \mathrm{x}$ mol -1 and $\mathrm{cm}-1$

$103=$ conversion factor from $\mathrm{g}$ in $\mathrm{mg}$.

\section{Results and discussions}

The obtained results of the tested samples are presented in Tables 1 to 4.

Table 1. Phenols, anthocyanin, antioxidant activity and $\mathrm{pH}$ of Wild Cherry (Banya, Karlovo)

\begin{tabular}{|c|c|}
\hline Indicator & Quantity \\
\hline Common phenols & $1,67 \pm 0,02 \mathrm{mg}$ GAE $/ \mathrm{g}$ fresh weight \\
\hline Common anthocyanin & $0,44 \pm 0,01 \mathrm{mg} / \mathrm{g}$ fresh weight \\
\hline Antioxidant activity, DPPH method & $16,20 \pm 0,10 \mathrm{~m} . \mathrm{mol} \mathrm{TE} / \mathrm{g}$ fresh weight \\
\hline $\mathrm{pH}$ & 3,94 \\
\hline
\end{tabular}


Table 2. Phenols, Anthocyanin, Antioxidant Activity and $\mathrm{pH}$ of the Early Cherry Van (Radilovo)

\begin{tabular}{|c|c|}
\hline Indicator & Quantity \\
\hline Common phenols & $1,15 \pm 0,02 \mathrm{mg}$ GAE / g fresh weight \\
\hline Common anthocyanin & $0,22 \pm 0,01 \mathrm{mg} / \mathrm{g}$ fresh weight \\
\hline Antioxidant activity, DPPH method & $11,17 \pm 0,10 \mathrm{~m} . \mathrm{mol} \mathrm{TE} / \mathrm{g}$ fresh weight \\
\hline $\mathrm{pH}$ & 4,19 \\
\hline
\end{tabular}

Table 3. Phenols, Anthocyanin, Antioxidant Activity and $\mathrm{pH}$ of the Van (Isperihovo)

\begin{tabular}{|c|c|}
\hline Indicator & Quantity \\
\hline Common phenols & $0,75 \pm 0,01 \mathrm{mg}$ GAE/g fresh weight \\
\hline Common anthocyanin & $\begin{array}{c}0,05 \pm 0,001 \mathrm{mg} / \mathrm{g} \text { fresh weight }(50,0 \pm 1,0 \\
\text { micro g/g fresh weight })\end{array}$ \\
\hline Antioxidant activity, DPPH method & $9,92 \pm 0,06 \mathrm{~m} . \mathrm{mol} \mathrm{TE} / \mathrm{g}$ fresh weight \\
\hline $\mathrm{pH}$ & 3,70 \\
\hline
\end{tabular}

Table 4. Phenols, Anthocyanin, Antioxidant Activity and $\mathrm{pH}$ of the Cartilage Bing or Bigato Burla (Novo selo)

\begin{tabular}{|c|c|}
\hline Indicator & Quantity \\
\hline Common phenols & $0,57 \pm 0,01 \mathrm{mg}$ GAE / g fresh weight \\
\hline Common anthocyanin & $\begin{array}{c}0,02 \pm 0,002 \mathrm{mg} / \mathrm{g} \text { fresh weight }(24,4 \pm 2,0 \\
\text { micro g / g fresh weight })\end{array}$ \\
\hline Antioxidant activity, DPPH method & $7,88 \pm 0,01 \mathrm{~m} . \mathrm{mol} \mathrm{TE} / \mathrm{g}$ fresh weight \\
\hline $\mathrm{pH}$ & 3,97 \\
\hline
\end{tabular}

The results presented are the mean values of at least three parallel tests.

The total phenols of the samples we studied are in the range of 0.57 to $1.67 \mathrm{mg} \mathrm{GAE} / \mathrm{g}$ fresh weight.

Total anthocyanin in the samples we tested was in the range of 0.02 to 0.44 $\mathrm{mg}$ / $\mathrm{g}$ of fresh weight. Antioxidant activity of 7.88 to $16.20 \mathrm{~mol} \mathrm{TE} / \mathrm{g}$ fresh weight $\mathrm{pH}$ of 3.70 to 4.19

\section{Conclusion}

1. The common phenols show the highest value in the Wild Cherry (Banya, Karlovo) - $1.67 \mathrm{mg} \mathrm{GAE} \mathrm{/} \mathrm{g} \mathrm{fresh} \mathrm{weight,} \mathrm{followed} \mathrm{by} \mathrm{Early} \mathrm{Van}$ Cherry (Radilovo), Van (Isperihovo), Cartilage Bing or Bigato Burla (Novo Selo). This indicator therefore depends on the altitude of the cultivated cherries.

2. The common anthocyanin is highest in the Wild Cherry (Banya, Karlovo), followed by Early Van (Radilovo), Van (Isperihovo) and Cartilage Bing variety or Bigato Burla (Novo selo). 
Common anthocyanin is highest in early sorts of cultivated cherries. In later ripening varieties of cultivated cherries, the value of common anthocyanin is significantly lower. In addition, this indicator depends on the altitude of the cultivated cherry.

3. The antioxidant activity is highest in the variety Wild Cherry (Banya, Karlovo), Early Cherry Van (Radilovo), Van variety (Isperihovo) and Cartilage Bing variety or Bigato Burla (Novo Selo). Therefore, this indicator depends on the altitude and ripening time of the fruit.

4. The $\mathrm{pH}$ indicator is highest at early ripening and rising at high altitude varieties.

5. In the current study of the sorts of cherries there is no direct correlation between the parameters: $\mathrm{pH}$ and antioxidant activity.

\section{References:}

1. Papanov SI, Zhelev I, Petkova EG, Proichev V, Kuzmanov B, Traykova $\mathrm{N}$ et al. (2009) Feeding habits - risk and protective factor for development of chronic infectious diseases. Social Medicine;1/2:37-38.

2. Petkova EG, Dimitrova Z, Papanov SI, Hadjidekov V.(2011) Ionizing Radiation - one of the reasons for formation of free radicals. Archives of The Balkan Medical Union; 46:221-5

3. Petkova EG, Dimitrova Z, Papanov SI, Traikova N, Hadjidekov V.(2011) Ionizing radiation-one of the reasons for formation of free radicals. Archives of the Balkan Medical Union ; 4:221-6.

4. Papanov SI, Ivanov K, Peykova L, Obreshkova DP, Petkova EG.(2011) Automation, analysis and sterilization of drugs with ultrasound. Pharmacia; 59:96-102

5. Papanov SI, Hadjieva B, Koleva N.(2014) Rapid-rp hplc method for estimation of captopril from tablet dosage form; International Journal of Biology, Pharmacy and Allied Sciences;3:317-25.

6. Petkova V, Tsvetkova DD, Obreshkova DP, Dimitrov M, Papanov SI, Atanasov P. (2014) Validization of TLC densitometric method for quality control of amoxicillin in dosage drug products. World Journal of Pharmacy and Pharmaceutical Sciences ;3:995-1008

7. Papanov SI, Georgieva M, Obreshkova DP, Atanasov P.(2014) Analytical survey comparison of some beta-lactam antibiotics used in practice. Pharmacia ;61:55-64

8. Ivanov K, Ivanova S, Doncheva D, Georgieva M, Pankova S, Zlatkov B et al.(2015) Analytical Methods for quality and quantity control of energy drinks and food supplements, containing amino acids. International Journal of Nutrition and Food Sciences;4:14-7 
9. Papanov SI, Pankova S, Ivanov K, Ivanova S, Doncheva D, Pencheva I.(2015) Analytical Methods for Quality and Quantity Control of Food Supplements, Containing Caffeine; International Journal of Nutrition and Food Sciences ;4:9-13

10. Pankova S, Tsvetkova,D, Ivanov K, Papanov SI, Ivanova S.(2015) Validation of TLC - densito metric method for identification and determination of estradiol. Pharmacia;62:3-9

11. Ivanova S, Ivanov K, Ivanova SA, Papanov SI, Obreshkova DP.(2015) The effects of treatment with prasterone (DHEA) on circulating hormones, body composition and muscle strength in men and women. Pharmacia ;62:36-42.

12. Papanov SI, Petkova EG, Ivanova SD, Ivanova SA.(2016) Caffeine the most abused psycho-active substance (survey conducted among students and their parents). International Journal of Biology, Pharmacy and Allied Sciences;5:504-12

13. Ivanova S, Ivanov $\mathrm{K}$, Mladenov $\mathrm{R}$, Papanov SI, Ivanova $\mathrm{S}$, Obreshkova DP et al.(2016) Food supplements with anabolic and androgenic activity - UHPLC analysis of food additives, containing Tribulus Terrestris extract. World Journal of Pharmacy and Pharmaceutical Sciences ;5(3)6-13

14. Papanov SI, Petkova EG, Ivanova S, Obreshkova DP, Petkova V.(2016) Apples from variety golden delicious, red delicious, greysmith - an antioxidant characteristics. World Journal of Pharmacy and Pharmaceutical Sciences ;5(8):8-13 